\title{
Retraction Note: Strong limiting behavior in binary search trees
}

Peishu Chen ${ }^{*}$ and Weicai Peng

\section{"Correspondence:}

peishu_chen@163.com

Department of Mathematics,

Chaohu University, Chaohu, 238000,

P.R. China
The paper [1] contains some ethical problems, so the authors were advised by the editor to retract their paper and resubmit it after corrections.

Received: 13 August 2013 Accepted: 14 August 2013 Published: 30 August 2013

References

1. Chen, P, Peng, W: Strong limiting behavior in binary search trees. J. Inequal. Appl. 2013, 60 (2013)

doi:10.1186/1029-242X-2013-416

Cite this article as: Chen and Peng: Retraction: Strong limiting behavior in binary search trees. Journal of Inequalities and Applications 2013 2013:416.
() 2013 Chen and Peng; licensee Springer. This is an Open Access article distributed under the terms of the Creative Commons Attribution License (http://creativecommons.org/licenses/by/2.0), which permits unrestricted use, distribution, and reproduction in any medium, provided the original work is properly cited.
Submit your manuscript to a SpringerOpen ${ }^{\circ}$ journal and benefit from:

- Convenient online submission

- Rigorous peer review

- Immediate publication on acceptance

- Open access: articles freely available online

- High visibility within the field

Retaining the copyright to your article

Submit your next manuscript at $>$ springeropen.com 